\title{
Educationally Game-based Personalized Learning Improves Learners' Literacy Across Disciplines
}

\author{
Dr. Ann Hilliard, Dr. Harriett F. Kargbo, \\ Associate Professor, Bowie State University - U.S.A. \\ Assistant Professor, Coppin State University - U.S.A.
}

\begin{abstract}
Game-based personalized learning in a common way enhances the learning experiences for the learner in a more proficient and timely manner. Game-based learning can simulate real-world application and experiences for learners and facilitators of instruction. The learner can promote and lead educational learning activities to enhance skills and knowledge in a variety of ways. In our schools and universities today, learners are exposed to a lot of technology applications. Using games through the application of technology provides the learner with lots of hands-on activities. Gaming activities are highly engaging and it helps the learner to find ways of solving problems by various means. Using technology games gives the learner also immediate feedback of a skill obtained or mastered. Educationally game-based learning is designed with the purpose of helping the learner to interact within an organizational environment by learning skills that improve literacy in various disciplines. Educational game-based learning is just another way to incorporate learning through the use of different media devices. Learners today have access to a wide range use of emerging technologies as they learn coursework in educational settings within the school and beyond environment.

Facilitators of instructional delivery services must continue to seek ways to address how learners learn best. By using game related activities, the facilitator has the opportunity to add value to a variety of instructional enhancers. With the effort of improving literacy, the instructional facilitator can use games to help the learner gain a variety of literacy experiences in an engaging and confident manner in a number of subjects or disciplines across the curriculum. Using a variety of games does not have to be expensive. Instructional facilitators can select some off the shelf games or online games, if incorporated properly, could be effective for use to drive learning performance and instructional activities (Sandford, Ulicsak, Facer \& Rudd, 2006). The intent of this article is to give research findings related to game-based personalized learning. This study will focused specifically on definition of game-based personalized learning, theorists, value and benefits, learning strategies, simulations and application, literacy booster, engagement and motivation, linkage and impact, and how scholarly significant is game-based learning.
\end{abstract}

Keywords: game-based learning, literacy benefits, motivating learners

\section{INTRODUCTION}

Today, teachers have a broader range of delivering instructional services to students. With the continued availability of technology being used as a tool in many settings, teachers in schools have access to utilizing a variety of ways to reach the needs and interests of students. Teachers are able to personalize their instructional delivery services to a diverse group of students with multiple-learning styles. By using educational game-based learning, this affords teachers another way to fully engage students in their own learning, improve retention and decision making (Chow, Kelly \& Maes, 2011).

Video games are highly engaging, and there is great interest in how to harness their power to support teaching and learning in schools. Researchers have studied educational video games and simulations to determine how they can effectively support the instructional process (Aguilera de \& Mendiz, 2003). Learners have different learning styles and the use of game-based learning gives the teacher optional ways of providing learners with many modalities in addressing the leaner's specific learning need. If planned well and implemented with learners in mind, the teacher can begin to find a variety of ways to be innovative by offering learners choices in how they may wish to engage in their own learning and how to solve problems during their learning experiences in and out of the classroom. Using game-based learning activities, the teachers are able to personalize their instructional delivery services to a diverse group of learners with multiple-learning styles. By using educational game-based learning, this affords teachers another way to fully engage students in their own learning (Krumholz, 2011). There are pros and cons about the validity of a teaching tool using a game. 
Whatever it may take to get learners interest in learning is vital in the educational and home environment. Based on research, nearly 65 percent of learners are motivated to learn when using an electronic device or tool. Based on a national survey over 75 percent of teachers k-8 grade are using game-based learning tools in schools to enhance the instructional delivery process. (Cooney, 2015). However, the effectiveness of game-based learning from an evaluative point of view regarding success for learner outcomes is still under scrutiny by many researchers.

\section{Definition of Game-Based Learning}

By definition, digital gaming can be simply expressed by being an interactive multimedia with dynamic elements that are under the control of the learner or teacher. Many digital games may be given repetitive action on the part of the user. The games and simulations are highly interactive. With many users, the controlled features of digital games are major reasons why learners enjoy using such devices. Learners can enjoy manipulating digital gaming control devices. If structured properly, learners can participate in mastering relevant educational information in class that is academically sound (Rieber, 2005). Educationally gamebased learning is designed with the purpose of helping the learner to interact within an organizational experience by learning skills and knowledge to improve literacy. Educational game-based learning is just another way to incorporate learning through the instructional process. Teachers, however, must continue to seek ways to address how learners learn best. By using game related activities, the teacher has the opportunity to add value to a variety of instructional enhancers. With the effort of improving literacy, the teacher can use games to help the learner gain a variety of literacy experiences in an engaging manner in a number of subjects or disciplines across the curriculum (Kebritchi, Hirumi \& Bai, 2010).

\section{Purpose of this Study}

The purpose of this study is to identify factors that encourages learners to be actively engaged and motivated in their own personal learning by using educational games. This study further states the values and benefits of game-based learning that promotes simulated experiences prior to an actual real-life experience.

\section{Impact Factors of Game-Based Learning according to Many Theorists}

In the learning environment, game-based learning can help to motivate students especially when students are participating in competitive activities. According to Rai \& Beck, 2011, especially in mathematics, game-based learning has no meaningful impact on student achievement. However, other theorists believe that online-based game models used for education, motivation has a direct correlation with improved outcomes of student learning (Chen, Yang, Wu \& Chiang, 2012). It is strongly suggested that the teacher's enthusiasm in the integration of a learning game is a key factor also in the academic success of that game (Kebitchi, 2010). Classroom games also increase teacher motivation too, but their effects on classroom successes are unclear (Shelton \& Scoresby, 2011). The quality of classroom instructional tools used is strongly influenced by teacher effectiveness. A study conducted by (Reese \& Wells, 2007), stated that games can cause motivation and achieving learners to become more so and unmotivated and underachieving learners to become more so as well, but have an overall positive effect on learners' confidence and achievement. Looking at outcomes, matching theoretical games can help to organize and assess their efficacy in achieving learning goals. Game theory can be used to assess classroom resources and materials by the effect on motivation as well as learning targets (Wilson, 2009). Many theorists have been identified within this study; however, the researchers believe that there is no substitute for high quality teaching in all learning environments. The teacher is the key individual in helping learners to participate in meaningful learning experiences in a productive manner for their own learning. Again, the teacher is the key to guiding and facilitating effective teaching and learning even when games are used in the process (Becker, 2007).

\section{Digital Game Theory}

The digital game learning theory enables the user to engage in and experiment with practical game designs (Becker, 2005). The user of the game will also be able to explore theories and concepts which can be used to analyze the formal characteristics of games and use them in different learning environments. The concept and use of games can bring different types of pleasure and value to the user in a contemporary environment (Professor Richard Bartle, University of Essex). Game-theory can be used to gauge the effectiveness of the curriculum methods as well as having an impact on motivation and achievement (Stull, 2004). Addressing the framework's micro-level of game-based learning suggests that the learner's challenges or obstacles that the learner must solve the nature of the intended focus of a specific game and the possible action in order to reach the desirable outcomes. However, identifying a suitable framework for game-based learning has not been easy based of the views of designers, because each game may differ in the target game genre and information may not be applicable (Choi, Huang, Jeffrey \& Baek, 2012). When learners through trial 
and error explore learning that can lead to the skills and knowledge of the game information being played that is a positive result. The learner is also motivated by the pleasure of mastering the game, because the learner feels in control of his/her efforts (Koster, 2005).

\section{Benefits of Game-Based Learning}

Learning games can help students to contextualize and apply lesson content to themselves and real life application. A common definition for contextual intelligence to promote personal learning is the ability to quickly and intuitively recognized and diagnose the dynamic contextual variable inherent in an event or circumstance and results intentional adjustment of behavior in order to exert appropriate influence in that context (Abram, 2009).

Competitive game-based learning can provide extra motivation to reach goals in a learning setting, especially when learners are made aware of extrinsic motivation according to many theorists (Burguillo, 2010).

There are many benefits to game-based learning conceptually as follows:

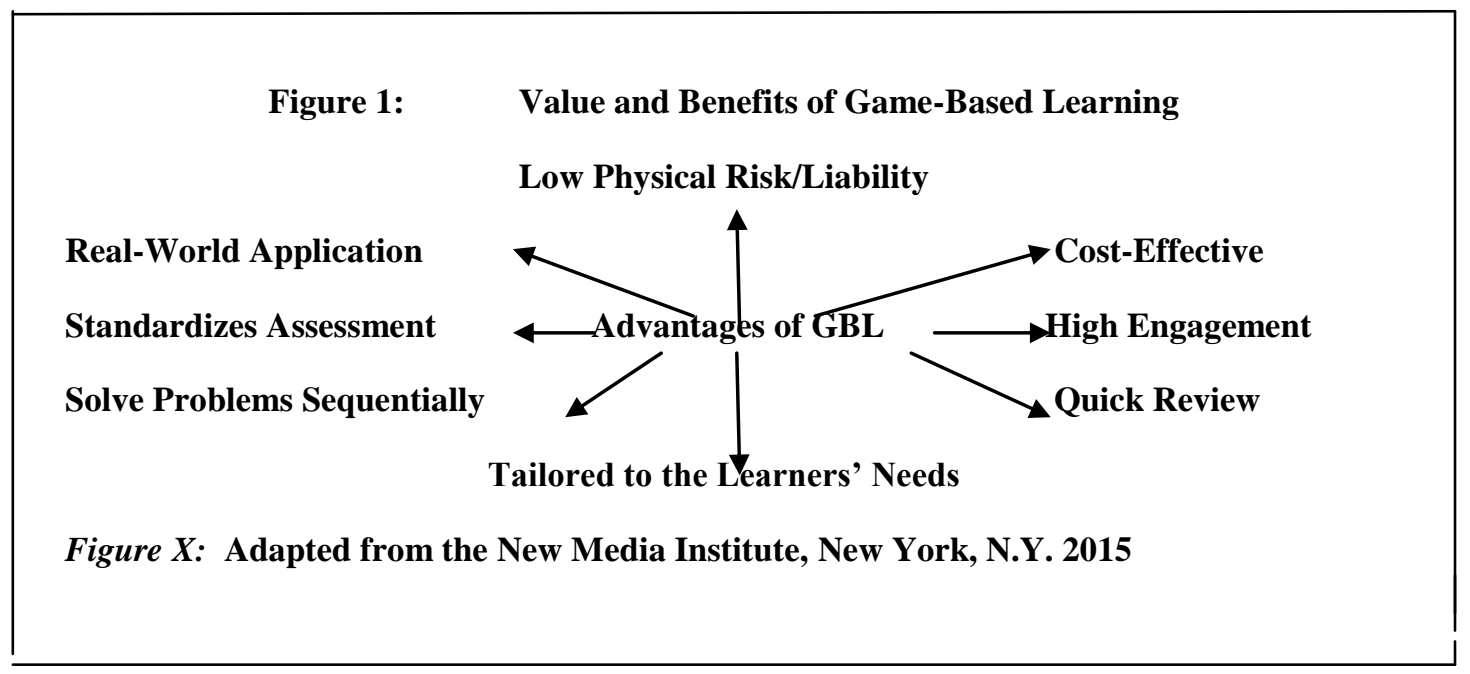

To progress in a game is to learn. When learners are actively engaged with a game, individual minds are experiencing the pleasure of grappling with (and coming to understand) a new system or how to use the system. This is true whether the game is considered "entertainment" or otherwise (Hagel \& Brown, 2009).

\section{Game-Based Learning Provides Active Learning Strategies}

Games methodically provide the learner with new and varied learning environments that meet his or her own learning style. Active learning through the use of gaming has shown a positive impact with learners by allowing them to actively participate in a learning project instead of passively listening to lectures or watching videos with educators assigning games as pre- and post-tests, reviews, and even as homework assignments (Annetta, 2008). When K-12 learners are learning to play games, they are in fact learning a new literacy or language that is defined above and beyond traditional reading and writing, but through multiple interactions including images, text, diagrams, symbols, and movement (Gee, 2007). These multiple interactions need correct interpretations for the learner to master the game resulting in out of the box thinking and risk taking which are based on active learning. Active learning principles focus on games requiring players to use their time in passive learning and reflective thinking, which generates information from this type of learning through instant feedback and the opportunity to determine additional game solutions (Gee, 2007).

An active learning strategy can be defined as an engaging activity that requires the learner to perform an educational action. The teacher can be sure that each learner has participated in the active learning experience based on evidence of data from the game application tool used in the learning process. Active learning strategies could be individual or group work. The learning strategies should be organized in a constructive manner to ensure effective ways of involving learners in the learning process. Active learning strategies may also include but not limited to brainstorming activities, peer and self critiques of work and role playing (Miller, Chang, Wang, Beier, \& Klisch, 2011). 
There are many benefits to games and simulations in learning. Educational games and simulations have been found to be effective in motivating students to learn (Ke, 2008; Papastergiou, 2009; Tüzün, YilmazSoylu, Karakus, Inal, \& Kizilkaya, 2009), and games that encourage exploration may be particularly engaging to learners, especially girls (Kinzie \& Joseph, 2008). An example of a game that fosters exploration is Discover Babylon, in which young learners travel through Mesopotamian time using math, reading and writing skills.

Some games and simulations allow learners to explore and create materials that they could not work directly with in real life. For example, Chemsense provides an environment in which learners can explore chemical processes and see the effects of changes. These open environments can also help learners to correct errors and misconceptions in their thinking by allowing them to test out hypotheses. Simulations can enable learners to develop familiarity with an activity before they engage in it. As an example, with Froguts, learners can use an interactive computer program to proceed fully through a frog dissection before attempting dissection of an actual frog in real-life. Learners who use simulations report that they feel more confident in their skill competence when later working with real materials (Ronan \& Elihu, 2000).

\section{Value of a Simulated Experience}

Using games to teach skills for real-world activities, the learner can make mistakes and improve upon the deficit in a quick turnaround manner. Therefore, the learner making the mistake can go back to improve upon the skills needed. The learner can also personally engage in decision-making, by taking a different way to solve the proposed problem in a simulated experience. The simulated experience can provide the learner with a life-like experience. The simulated experience can also educate the learner too, in the workings of the sectors a whole virtually without utilizing the real official environment of action. Again, the simulated object can be used to educate and inform best practices for skill and knowledge development for the learner (Brom, Presuss \& Klement, 2011).

\section{Use of Games in the Classroom Environment}

If used in an appropriate manner, many types of games could be used in an educational environment that enhances teaching and learning in various disciplines. Games could be used to master specific coursework, reinforce the development of a skill, expand concepts, gaining knowledge of people and their culture and a number of other important informational activities (McGonigal, 2011).

Learning by doing is an approach that makes sense in an educational environment. In classrooms today, learners have an attitude of wanting to be engaged in their own learning experiences. Students want to have their hands, eyes and minds in the classroom "doing something." The "doing something" is not a new phenomenon, but a reason for being in school. By using gaming devices in the classroom can help to personalize the way learners engage in learning based on their individual needs. Gaming or digital devices help learners to engage in interactive tasks that may represent real-world experiences. Real-world experiences help students to see the relevance to why they are learning something. Learners will be able to apply and link what they are learning to a realistic situation. Technology today is evolving fast and this is an opportunity to deliver instruction and learning experiences in more ways than one venue by the teacher to improve student learning. If planned carefully, teachers may soon enjoy the many ways that digital games are able to enhance the instructional delivery process. However, another school of thought by critics that digital gaming in the classroom can hinder classroom deep learning in reading and males and females do not benefit from these experiences on an equitable level. However, the more progressive thinkers believe that digital gaming is a positive tool for educating people and changing their behavior (Bourgonjon, Valcke, Soetaert \& Schellens, 2010)

\section{Enhancing Learning}

Our learners today have been exposed to a lot of technology applications; therefore, the natural order of learning could be enhanced by the use of digital games. Using games through the application of technology provides the learner with lots of hands-on activities. Gaming activities are highly engaging and it helps the learner to find ways of solving problems by various means. Using different gaming applications, gives the learner also immediate feedback as a key place of reference. A place of reference tells the learner and user of the game that this is a designation of the game. Gaming may also give the learner the opportunity to experience practice for real-world application of skills and knowledge. Learners respond to the gaming learning experience for many of the following reasons because the information is: 1.) What the learner wants to learn. 2.) 
What the learner sees as a benefit. 3.) What the learner believes it will help him/her to grow. 4.)What the learner sees as relevant, purposeful, meaningful and current. 5.) What the learner sees as different but enjoyable (Kapp, 2012).

The learner wants to learn when information is perceived as being important, timely, valuable, and useful. The learner may wish to be engaged in mastering skills, if the learner sees the skills as being significant. Beyond the world of intentional benefit, the learner's behavior is one of choice. If the learning is personalized and significant to the learner then the opportunity will be of personal development and engagement. When the learner is in a formal environment such as the classroom, the learner may continue to be directed by the teacher to complete certain tasks as an individual or in a group activity. The group activity could suggest that the teacher is encouraging learners to participate in learning communities that are driven by tasks. Learners participating in learning communities will gain more skills and knowledge about the importance of sharing knowledge with others in a collaborative manner (Fengfeng, 2008).

\section{Building Literacy Skills}

If the game is well designed, the learner will be able to repeat the experience of mastery over and over again toward perfection. Games could be used to build literacy skills in reading and mathematics, if enjoyed, a great feeling of entertainment and well being will exist (Yip \& Kwan, 2006). There are many steps involved in reading as one would tell a story in a narrative and sequential manner according to game theorist (Henry Jenkins, Eric Zimmerman and Mary Flanagan, 2012). These theorists believe that the influence of new media and gaming have a place within the narrative of traditional storytelling as an example. The question could be put forward, just how does the leaner learn? With certainty, the leaner will probably learn more in a comprehensive manner, if the experience is relevant, meaningful and enjoyable (Gee, 2007).

\section{Teacher Balancing Learning Engagement}

Research evidence suggests that gaming helps to keep learners more engaged in their own learning. It is important for the teacher to provide the learner with gaming opportunities as another way of learning. Learning should and could be fun; however, the teacher must make sure that the pedagogical approach to learning is clear. In essence, the teacher must continue to make the balance between fun and learning quality skills and knowledge that is relevant for all learners is what is important. The teacher should make sure that the academic content for the learner is relevant for problem-solving through facilitation with appropriate guidance, procedures are followed and keeping the educational environment on target based on coursework expectations and standards (Schaaf, 2012).

Educational game-based personalized learning could help the teacher to use another path of infusing the instructional delivery process such as making the learning more relevant, active and engaging learning, giving learners choices and letting learners know that their thoughts are valued, the need to build a community of learners through collaboration, demonstrating that there is an acknowledgement that learners do learn differently and the teacher is willing to make it possible by offering students choices. It is important for the teacher to maintain high expectations for all students and creating and maintaining an environment that is conducive to learning (Miller \& Robertson, 2011). There is a strong agreement among most researchers that digital gaming can promote learning, but what is important is "positive learning" that builds needed skills in competitive societies (Shaffer, Squire, Halverson, \& Gee, 2005). B B allowing the learner to gain new and improved knowledge through different modalities, the teacher is indicating to learners that the teacher believes that learning can take place by various means and ways by the use of games. If learning is meaningful and enjoyable, the learner sees learning as being relevant (Kenny \& McDaniel, 2011).

\section{When is the Learner Motivated?}

If schools are learner-centered, then there must be evidence that teachers have provided the opportunity for learners to be engaged in their own learning. When learners are bored, the chances are that these learners are not engaged in the learning process that meet their individual needs and interests. Learning is a responsive nature of acquired skills and knowledge. This opportunity for learners is needed for the learners to see and believe that "whatever is to be learned has relevancy" to the learner's life. In the classroom or an outside classroom assignment, the learner needs interactive and meaningful experiences. When the learner can see what is being learned can be connected to the real-world, the learner is generally motivated, because what is being learned has a real purpose (Ambrose, 2013).

\section{Linking and Connecting the Learning Experience to Relevancy}


According to James P. Gee (2005), there is some value added to game-based personalized learning when the experience is linked to how the learner learns in the context of the game environment educationally. If the learning experience to the learner is connected to: 1.)Applicable job performance. 2.) Relevant to the learning objective. 3.)An encouraging way to be active and critical in the learning process. 4.) Exploring the world by doing something meaningful. 5.) Acting experiencing real-world foci. 6.)Specific goals in a variable game setting. 7.) Activities that are interesting and critical in the gaming experience. 8.) Non- passive, learning but interactive learning. 9.) Making choices through experimentation that are mature and meaningful. 10.) Seeing performance evaluations as a way to improve learner outcomes. This is when relevancy stands the "test of time."

\section{Solving Problems for Real-World Application}

Gaming today is used in a variety of organizations to training individuals how to solve real-life problems that are commonly found in emergency respondents, military operations, and medical activities. Therefore, the impact of gaming even for adults could have a broad-based meaning to the learner. By going through a gaming exercise, the learner may gain an experience of realism "what it could be, but not an absolute in the real-world." The gaming constructive experience could give the learner eventually a way to see a platform of how what readiness looks like through the gaming lenses. The learner will have a stronger idea as to the kinds of skills and knowledge that one would need to solve problems. The learner will further learn the processes in detail how things are done and why. The learner will master skills related to certain jobs and the use of tools applicable to certain jobs in education, health, and the military as specific examples (Vos \& Denessen, 2011).

\section{METHODOLOGY}

The methodology of gamification in the educational environment addresses the game-design principles to help change the instructional setting by the teacher in order to offer the learner more fun and relevant activities which engages and motivates the learner. Some of the principles are at the levels of learning, challenges and the mastery of skills observed through the assessment of points, and immediate feedback to the learner (Kapp, 2012).

Using the simulation approach to learning, games stimulates the learner because the learning yields greater comprehension, application, analysis, synthesis and assessment. The major methodology behind gamebased learning does not deploy the assessment of the learner's ability totally, but it teaches the learner how to apply and use theory of real-life situations which has more meaning to the learner especially in the area of problem solving in group settings or the individual playing the game. By using game-based personalized learning, learners will be able to relate to what they have learned in an applicable manner (Rieber, Tzeng, \& Tribble, 2004). Learners today are able to use a traditional approach in theory in game-based learning. However, using the traditional theory in game-based learning, learners read texts, take notes and answer questions is not frequently desirable. This method is not the most exciting way to learn based on input from learners who are technologically savvy. The traditional approach does not always afford learners the linkage between their learning and real-world application (Carnegie Mellon Eberly Center, 2013) .

In the world of teaching by delivering instructional services at all educational levels, faculty or teachers could have a stronger impact on learners' acquisition of learning by incorporating game-based learning experiences for learners. The attention level of learners may be a challenge sometimes. Qualitative data suggest that game-based learning methodology could impact learner's interests in learning a subject and could be a motivator for keeping the learner engaging and focusing on learning relevant materials that have real-world application (Baxter \& Jack, 2008). Data further suggest that game-based learning may influence faculty or teachers to re-assess the way in which they teach. It is essential that learners' attention and enthusiasm be a big part of ensuring learners' success by teacher or faculty planning and implementing instructional delivery services. Game-based methodology has the potential to transform classroom settings into environments that promote effective and purposeful learning for all learners (Silvia, 2012).

\section{Research Question and Implications}

The overarching research question in this study is: - does game-based learning actively engage learners in their own learning? The answer to this question is yes which is further communicated in the overall findings for this study. While learning, learners are playing games and this makes it an easy sell for the teacher or faculty member to keep the learner's interest both in and out of the classroom. Therefore, more learners are motivated and engaged in their own learning. Game-based personalized learning encourages self-reliance and self-determination in reference to the learner's ability to continue engaging in the mastery of the game in various settings. The level of engagement and interaction with games expands the competition and rewards of the 
gaming experience plus the learning experience goes far beyond the classroom when using game-based learning (Arnseth, 2006).

Research findings further suggests that by learners participating in game-based learning, learners are motivated and are engaged more in their own learning experiences. How is this information measured? Several studies have measured such outcomes by incorporating learner observations and time-on-task. The essence of time-on-task is an indicator of the learner's engagement on a task (Annetta et al., 2009; Fengfeng, 2008a).

Other findings on game-based learning can have many benefits, but how gaming is impacting teaching and learning has not been fully determined. Therefore, more research needs to be done. Gaming can be used to transform the way learners master educational skills and knowledge in a variety of ways (Annetta, Minogue, Holmes \& Cheng, 2009). Learners can be exposed to a different structure of educational instruction and lessons for learning a particular skill in a personalized manner. Through game-based learning the learner 's performance could be monitored and evaluated to determine the degree of mastery in a quick manner (Markovic, Petrovic, Kittl \& Edegger, 2007).

Another body of research findings suggests that learners learn more when they are involved in their own learning. Gaming, if enjoyed, helps to set the stage for learning for the learner. Using a video model for learning as an example, the learner could be exposed to units of instruction in a personalized manner. When learners engage in their own learning, they have the capacity to participate in their own learning experiences and style without waiting on the teacher to give them every step of the way. The learner can also seek higher expectations as being self-directed in the learning process (Salen, 2008).

\section{Overall Findings}

Several qualitative studies suggests the following about game-based personal learning engagement and motivation. 1.) Learners are motivated, because of the praise, encouragement and reinforcement, confidence and are motivated to continue the task (Ya-Ting, 2012). 2.) Games expand learner's curiosity and are enjoyable (Papastergiou, 2009). 3.) Teachers say when learners play the game, they want to learn more and pay more attention, because the learner likes to pass the game missions (Kebritcchi, 2010). 4.) Learners who learn through using video games appear to be linked between the observed increased in both the level of the challenge posed by the task (Liu et al., 2011). 5.) The feeling of being positive psychologically is felt by the learner (Csikszentmihalyi, 1996).

\section{Game-Based Learning Can be Scholarly Significant}

Game-based learning is scholarly significant because it allows diverse learners to be able to: 1.) Receive customized experiences to fit the learner's ability and interests. 2.) Engage in interactive tasks that could simulate real-world experiences. 3.) Improve brain functions, while others may reverse the loss associated with aging. 4.) Encourage decision-making that could drive progress. 5.) Expand the teaching capacity of literacy skills across disciplines. 6.) Expose to mastering new languages, build vocabulary and participate in multitasking opportunities. 7.) Access information pertaining to current issues on law and educational policy. 8.) Provide the opportunities to connect in "real-time" with global communities. 9.) Participate in the evaluation process of tasks performed in various classes. 10.) Use research that supports the positive value and benefits of game-based learning in solving-problems and other related activities in the classroom or clinical settings that will impact the future use of games to promote learning in educational environments and many other settings (Shaffer, Squire, Halverson \& Gee, 2005).

\section{CONCLUSION}

Game-based learning using digital tools is another way to facilitate the instructional process for the young and adult learners. Learners have the opportunity to be directly involved in their own learning in a variety of modalities. Game-based personalized learning affords the learner the chance to virtually participate in a simulated environment that depicts some aspects of real-life experiences. Learning by using games offers learners to be engaged in the learners' own learning based their individual needs. Learners normally enjoy and find game-based learning to be fun and challenging sometimes. When learners have fun learning they are more motivated to learn new and challenging tasks. Game-based personalized learning promotes and encourages the learner to learn in and outside the classroom (Backlund \& Hendrix, 2013). Game-based learning allows the learner to focus on repeating the task until desired results are met. When learning is personalized, the learner has control over his or her own learning experiences through exploratory action. The 21 st Century classrooms and outside the classroom affords the learner many options to learn a new skill or gain new or improved knowledge. Many learners are able to successfully participate in multiple learning activities within a short period of time by using digital games (Prensky, 2001). 
The digital generational learners find that game-based learning is a natural way of obtaining objectives to meet current educational or organizational standards. The digital generation of learners using game-based learning is highly engaging and is fun and motivational. Today's learners enjoy teamwork and are competitive using game-based learning. Plus instead of waiting a long time for feedback from the teacher or trainer, the learner can received immediate feedback after completing a task digitally. Beyond games being fun, motivational, and engaging, the game-based learning experiences for learners with the guidance of the teacher or trainer can be personalized to meet the learner's individual needs. By involving learners in their own learning, the learner becomes the master of his/her skills, knowledge and personal development (Shaffer, Squire, Halverson, \& Gee, 2005).

The overall advantages, in summary, to game-based learning are as follows: cost -effective because of access, instructionally-driven, low physical risk and liability, standardization is specific, highly engaging in the learning process, learning is personalized, interactive with others is possible and activities can be assessed and the overall experience for learners can transfer sample actions to real-world application (Trybus, 2014). Finally, by involving learners in their own learning, the learner becomes the master of his/her skills, knowledge and personal development. By manipulating a game successfully when conducting an educational task, the learner can be reflective of the learning experience and will also have a better feeling about self (Fling, Smith, Rodriguez, Atkins \& Nixon, 1992).

\section{Information about the Authors}

Ann T. Hilliard is a tenured associate professor in the Department of Educational Studies and Leadership at Bowie State University. Dr. Hilliard holds an advanced professional certificate in school leadership administration. She has served as an international consultant in school administration and leadership in the U.S. and Asia. The author has presented research papers at a number of conferences and published her work in national and international peer reviewed refereed journals. She teaches classes related to policy, educational planning and evaluation, school law, human resources; and dissertation I/II and has served as chairperson on several dissertation committees. The author's interests include technology application in educational leadership and instruction, data assessment research, evaluation, curriculum and instructional leadership, international education and improving the dissertation experiences for doctorate candidates in higher education. Dr. Hilliard received her Ed.D. degree from George Washington University; M.S. degree from the Johns Hopkins University; M.A.T. degree from Trinity University; B.S. degree from Elizabeth City State University; and a Consulting Certificate from Harvard University. E-mail: draph1@juno.com

Dr. Harriett F. Kargbo is an assistant professor in the Department of Instructional Leadership and Professional Development at Coppin State University in Baltimore, Maryland, U.S.A. The author teaches school law, developing curriculum strategies, administering education programs, and counseling adult learners, and coordinates the Center for Adult Learning. The author's research focus is on educational leadership, teaching adult learners, study abroad learning, and hybrid and online instruction. Prior to teaching on the higher education level, the author has extensive experience as a K-12 teacher and administrator in an urban setting. Education includes degrees from Nova Southeastern University (Ed.D.); Howard University (M.Ed.); and Saint Augustine's College (B.S.).

\section{REFERENCES}

[1] Abrams, S.S. (2009). A gaming frame of mind: digital contexts and academic implications. Educational Media International, 46(4), 335-347.

[2] Aguilera de, M. \& Mendiz, A. (2003). "Video games and education," Computers in Entertainment, vol. 1, no. 1, article 1, 2003. View at Publisher • View at Google Scholar.

[3] Aldrich, C. (2009). Learning online with games, simulations, and virtual worlds: Strategies for online instruction. San Francisco, CA: Jossey-Bass.

[4] Allen, M. (2002, January). Discovery learning: Repurposing an old paradigm - How to make learning active and student-centered. Learning and Training Innovations Magazine. Retrieved from http:// www.elearningmag.com/.

[5] Ambrose,S.A. (2013). How learning works: Seven research-based principles for smart teaching. San Francisco, CA: Jossey-Bass.

[6] Annetta, L. A. (2008). Video games in education: Why they should be used and how they are being used. Theory Into Practice, 47(3), 229-239. doi:10.1080/00405840802153940. 
[7] Annetta, L.A., Minogue, J., Holmes, S.Y. and Cheng, M.-T. (2009). "Investigating the impact of video games on high school students' engagement and learning about genetics", Comput. Eol. 53, No. 1, pp 74-85.

[8] Arnseth, H.C. (2006). "Learning to Play or Playing to Learn - A Critical Account of the Models of Communication Informing Educational Research on Computer Gameplay", Game Studies, [Online] Vol. 6, No. 1, http://www.gamestudies.org/0102/squire/.

[9] Backlund, P. and Hendrix, M. (2013). "Educational Games - Are They Worth the Effort? A Literature Survey of the Effectiveness of Serious Games", Games and Virtual Worlds for Serious Applications (VS-GAMES), 2013 5th International Conference on, 11-13 Sept. $\quad$ 2013, pp 1-8.

[10] Barab, S. A., Gresalfi, M., \& Arici, A. (2009). Why educators should care about games. Educational Leadership, 67(1), 76-80.

[11] Barnett, S. M., \& Ceci, S. J. (2002). When and where do we apply what we learn? A taxonomy for far transfer. Psychological Bulletin, 128(4), 612-637. doi:10.1037/0033- 2909.128.4.612

[12] Baxter, P. and Jack, S. (2008). "Qualitative Case Study Methodology: Study Design and Implementation for Novice Researchers", The Qualitative Report, Vol. 13, No. 4, pp 544- 559.

[13] Becker, K. (2005). "How Are Games Educational? Learning Theories Embodied in Games", DiGRA 2005 Conference: Changing Views - Worlds in Play, Vancouver, Canada.

[14] Becker K. (2007). "Digital game-based learning once removed: teaching teachers," British Journal of Educational Technology, vol. 38, no. 3, pp. 478-488. View at Publisher · View at Google Scholar · View at Scopus

[15] Bogost, I (2011). How to Do things with Video Games, Minneapolis, Mn. University of Minnesota Press.

[16] Bourgonjon, J.., Valcke, M., Soetaert, R and Schellens, T. (2010). Students' perceptions about the use of video games in the classroom', Computers and Education, 54, 4, 1145-1156.

[17] Brom C, Preuss M, Klement D. (2011). Are educational computer micro-games engaging and effective for knowledge acquisition at high-schools? a quasi-experimental study. Comput Educ. 2011;57:19711988. doi: 10.1016/j.compedu.2011.04.007.

[18] Burguillo, J. C. (2010). Using game theory and Competition-based Learning to stimulate student motivation and performance. Computers \& Education, 55(2), 566-575.

[19] Chen, I.H., Yang, Y.T.C., Wu, W.C. \& Chiang, W.C. (2012). The Relationship between Academic Abilities and Internal/External Thinking Styles on Digital Game Flow Experience. In T. Bastiaens \& G. Marks (Eds.), Proceedings of E-Learn: World Conference on E-Learning in Corporate, Government, Healthcare, and Higher Education 2012 (pp. 911-918).

[20] Chesapeake, VA: Association for the Advancement of Computing in Education (AACE). Retrieved September 22, 2016 from https://www.learntechlib.org/p/41712.

[21] Chow, A. F., Kelly, C. W. \& Maes, J. (2011). Deal or No Deal: using games to improve student learning, retention and decision-making. International Journal of Mathematical Education in Science and Technology, 42, 259-264.

[22] Choi, B., Huang J., Jeffrey, A Baek, Y. (2013). "Development of a scale for fantasy state in digital games," Computers in Human Behavior, vol. 29, no. 5, pp. 1980-1986, 2013. View at Publisher . View at Google Scholar • View at Scopus.

[23] Csíkszentmihályi, M. (1996). Creativity: Flow and the Psychology of Discovery and Invention, New York, NY: Harper Perennial.

[24] Druckman, D. (1995). The educational effectiveness of interactive games. In D. Crookall \& K. Arai (Eds.), Simulation and gaming across disciplines and cultures: ISAGA at a $\quad$ watershed (pp. 178187). Thousand Oaks, CA: Sage Publications.

[25] Fengfeng, K. (2008b). Computer games applicable with alternative classroom goal structure: cognitive, meta-cognitive and affective evaluation', Education Technology Research and Development, 56, 5-6, 539-556.

[26] Fling, S., Smith, L., Rodriguez, T., Thornton, D., Atkins, E. And Nixon, K. (1992). Videogames, aggression and self-esteem', Social Behavior and Personality: an International Journal, 20, 1, 3945.

[27] Game-based learning GameLab experience (2013). Newsletter Serious Games Simulations http://www.gamelabeducation.com/en/why-does-the-game-based-learning-methodology- strengthenlearning/\#sthash.sjYrbBLn.dpuf.

[28] Gee, J. P. (2005). What would a state of the art instructional video game look like? Journal of Online Education, 1(6). 
[29] Gee, J. P. (2007). What video games have to teach us about learning and literacy (2nd ed.). New York, NY: Palgrave Macmillan.

[30] Hagel , J. , \& Brown, J.S. (2005). From push to pull: Emerging models for mobilizing resources . Unpublished working paper, October. Retrieved from edgeperspectives.com Press.

[31] Haystead, M. W., \& Marzano, R. J. (2009). Meta-analytic synthesis of studies conducted at Marzano Research Laboratory on instructional strategies. Retrieved from Marzano Research Laboratory website: http://www.marzanoevaluation.com/files/Instructional_Strategies_Report_9_2_09.pdf

[32] Joan Ganz Cooney Center, (2015). Level Up Learning: A National Survey on Teaching with Digital Games.

[33] Kapp, K. M. (2012). The Gamification of Learning and Instruction. Game-Based Methods and Strategies for Training and Education. Pfeiffer and Company.

[34] Kebritchi, M. Hirumi, A. And Bai, H. (2010). The effects of modern mathematics computer games on mathematics achievement and class motivation', Computers and Education. $55 . \quad 2,427-443$.

[35] Ke, F. (2008). A case study of computer gaming for math: Engaged learning from game play? Computers \& Education, 51(4), 1609-1620. doi:10.1016/j.compedu.2008.03.003.

[36] Ke, F. (2008). Computer games application within alternative classroom goal structures: cognitive, metacognitive, and affective evaluation. Educational Technology Research and Development, 56 $(5 / 6), 539-556$.

[37] Ke, F. (2009). A qualitative meta-analysis of computer games as learning tools. Handbook of Research on Effective Electronic Gaming in Education, 1, 1-32.

[38] Kebritchi, M., Hirumi, A., \& Bai, H. (2010). The effects of modern mathematics computer games on mathematics achievement and class motivation. Computers \& Education.

[39] Kenny, R.F.K. and McDaniel, R. (2011). 'The role teachers' expectations and value assessments of video games play in their adopting and integrating them into their classrooms', British Journal of Educational Technology, 42, 2, 197-213.

[40] Kinzie, M., \& Joseph, D. (2008). Gender differences in game activity preferences of middle school children: Implications for educational game design. Educational Technology Research and Development, 56 (5/6), 643-663.

[41] Klopfer, E., Osterweil, S., \& Salen, K. (2009). Moving learning games forward: Obstacles, opportunities \& openness.Retrieved from http://www.educationarcade.org/.

[42] Koster, R. (2005). A Theory of Fun for Game Design. Scottsdale, AZ: Paraglyph Press.Marina Papastergiou. (2009). Digital Game-Based Learning in high school Computer Science education: Impact on educational effectiveness and student motivation. Computers \& Education,.

[43] Krumholz, Honey. 2011). "Classroom Games Serve Many Purposes Here's How to Use Them!!” Priceless-teaching-strategies.com. n.d. strategies.com/classroom_games.html.

[44] Markovic, F., Petrovic, O., Kittl, C. and Edegger, B. (2007) 'Pervasive learning games: a comparative study’, New Review of Hypermedia and Multimedia, Vol. 13, No. 2, pp.93- 116.

[45] Marzano, R. J. (2007). The art and science of teaching: A comprehensive framework for effective instruction. Alexandria, VA: Association for Supervision and Curriculum Development.

[46] McDonald, K. K., \& Hannafin, R. D. (2003). Using web-based computer games to meet the demands of today's high-stakes testing: A mixed method inquiry. Journal of Research on Technology in Education, 35(4), 459-472.

[47] McGonigal, J. (2011). Reality is broken: Why games make us better and how they can change the world. New York: Penguin Press.

[48] Miller, D.J. and Robertson, D.P. (2011). 'Educational benefits of using game consoles in a primary classroom: a randomised controlled trial', British Journal of Educational Technology,42, 5, 850-864.

[49] Miller, L. M., Chang, C.-I., Wang, S., Beier, M. E., \& Klisch, Y. (2011). Learning and motivational impacts of a multimedia science game. Computers \& Education, 57(1), 1425-1433. doi:10.1016/j.compedu.2011.01.016.

[50] Papastergiou, M. (2009). 'Digital game-based Learning in high school computer science education: impact on educational effectiveness and student motivation', Computers and $\quad$ Education, 52, 1, 112.

[51] Prensky, M. (2007). Digital game-based learning. St. Paul, MN: Paragon House Publishers.

[52] Rai, D. and Beck J. E. 2011. Exploring user data from a game-like math tutor: a case study in causal modeling. In Proceedings of the 4th International Conference on Educational Data Mining (EDM). 307313. 
[53] R Reese, C., \& Wells, T. (2007). Teaching academic discussion skills with a card game. Simulation \& Gaming, 38(4), 546-555.

[54] Liu, C.C., Cheng, Y.B. and Huang, C.W. (2011). 'The effect of simulation games on the learning of computational problem solving', Computers and Education, 57, 3, 1907- 1918.

[55] Rieber, L., Tzeng, S.-C., \& Tribble, K. (2004). Discovery learning, representation, and explanation within a computer-based simulation: finding the right mix. Learning and Instruction, 14, 307-323.

[56] Ronen, M., \& Eliahu, M. (2000). Simulation--a bridge between theory and reality: The case of electric circuits. Journal of Computer Assisted Learning, 16 (1), 14-26.

[57] Salen, K. ed. 2008. The ecology of games: Connecting youth, games, and learning. MIT Press, pp. 27.8

[58] Sandford, R., Ulicsak, M., Facer, K. and Rudd, T. (2006). Teaching with Games: Using commercial off-the-shelf computer games in formal education. Bristol: Futurelab.

[59] Schwartzman, R. (1997). Gaming serves as a model for improving learning. Education, 118(1), 918.

[60] Schaaf, R. (2012). 'Does digital game-based learning improve student time-on-task behavior and engagement in comparison to alternative instructional strategies?' Canadian Journal of Action Research, 13, 1, 50-64.

[61] Shaffer, D.W. (2008). How Computer Games Help Children Learn. New York, NY: Palgrave Macmillan.

[62] Shaffer, D. W., Squire, K. R., Halverson, R., \& Gee, J. P. (2005). Video games and the future of learning. Phi Delta Kappan, 87 (2), 105-111.

[63] Shelton, B. E., Walker, A., Parlin, M., Scoresby, J., \& Duncan, S. M., (2011). Addressing Disparities of Motivation and Gender in Middle-School Literacy Education within Game Design. Technology, Knowledge and Learning.

[64] Silvia, C. (2012). The Impact of Simulations in High-Level Education. Journal of Public Affairs Education, University of Kansas, Vo.18, p.401.

[65] Squire, K. \& Jenkins, H. (2003). Harnessing the power of games in education. Insight, 3(1), 5- 33.

[66] Stull, A. T., \& Mayer, R. E. (2007). Learning by doing versus learning by viewing: Three experimental comparisons of learner-generated versus author-provided graphic organizers. Journal of Educational Psychology, 99, 808-820.

[67] Theory and Research-based Principles of Learning (2013). Carnegie Mellon Eberly Center for Teaching Excellence. (http://www.cmu.edu/teaching/principles/learning.html).

[68] Trybus, J. (2013). The New Media Institute's resident Gamed Based Learning and Communication, Carneighe Mellon University's Entertainment Technology Center.

[69] Vos, N., van der Meijden, H., \& Denessen, E. (2011). Effects of Constructing versus Playing an Educational Game on Student Motivation and Deep Learning Strategy Use. Computers \& Education. Vol. 56 Issue 1, 127-137.

[70] Weiss, T., \& Loebbecke, C. (2008). Online gaming adoption in competitive social networks: Combining the theory of planned behavior and social network theory. Proceedings of the Fourteenth Americas Conference of Information Systems, Toronto, ON, Canada, August $\quad$ 14th-17th, 2008.

[71] Wilson, K.A. et al., (2009). Relationships Between Game Attributes and Learning Outcomes. Simulation \& Gaming, 40(2), 217-266.

[72] Yaman, D. \& Covington, M. (2006). I'll take learning for 500: Using game shows to engage, motivate and train. san Francisco, CA: Pfeiffer

[73] Ya-Ting, C.Y. (2012). 'Building virtual cities, inspiring intelligent citizens: digital games for developing students' problem solving and learning motivation', Computers and Education, 59, 2, 365-377.

[74] Yip, F. W. M., \& Kwan, A. C. M. (2006). Online vocabulary games as a tool for teaching and learning English vocabulary. Educational Media International, 43(3), 233-249. doi:10.1080/09523980600641445. 